\title{
Dusulio intensyvumo sąsajos su eozinofily skaičiumi kraujyje sergant alergine astma
}

\author{
THE RELATIONSHIP BETWEEN DYSPNEA PERCEPTION AND BLOOD EOSINOPHIL \\ COUNT IN ALLERGIC ASTHMA
}

\author{
VIRGINIJA KALINAUSKAITĖ-ŽUKAUSKĖ, DEIMANTĖ HOPPENOT, KĘSTUTIS MALAKAUSKAS \\ LSMU MA Pulmonologijos klinika
}

\begin{abstract}
Santrauka. Ivadas. Greta daugelio veiksnių, galinčiu įtakoti dusulio suvokima, reikšmingos ịtakos turi ir patofiziologiniai procesai, vykstantys plaučiuose, pvz., kvépavimo taku uždegimas. Alerginès astmos patogenezèje svarbiausios uždegimo ląstelès yra eozinofiliai, kurie sukelia eozinofilinị kvépavimo taku uždegima, pasireiškianti padidejusiu bronchu reaktyvumu. Iki šiol nepakankamai ištirtos dusulio intensyvumo sąajos su kraujo eozinofilu skaičiumi sergant alergine astma. Tikslas. Ivertinti sergančiuju alergine astma dusulio intensyvumo sąsajas su kraujo eozinofilu skaičiumi kraujyje prieš ir po bronchu provokacijos Dermatophagoides pteronyssinus (D. pteronyssinus) alergenu. Metodika. Ištirta 11 sergančiųjų alergine astma (amžiaus vidurkis - 31,8 $\pm 9,3$ metu) kuriu plaučiu funkcija normali ir nevartoja įkvepiamuju gliukokortikoidu. Visiems tiriamiesiems atlikti bronchu provokaciniai mèginiai su metacholinu ir D. pteronyssinus alergenu. Dusulio intensyvumas vertintas matuojant Borgo skale sumažejus forsuoto iškvépimo tūriui per pirmają sekundę (FEV $\left.V_{1}\right)$ 20 proc. bronchu provokacijos alergenu metu $\left(P S_{20 A}\right)$. Eozinofilu skaičius kraujyje vertintas prieš ir praèjus 24 val. po bronchu provokacinio meginio su alergenu. Gauti duomenys apdoroti statistine programa "SPSS 23.0". Rezultatai. Vidutinis dusulio intensyvumas bronchu provokacijos su alergenu metu $\left(P S_{20 A}\right)$ buvo 2,97士2,31. Vidutinis kraujo eozinofilu skaičius prieš provokacinị mėginị alergenu buvo $0,36 \pm 0,25 \times 10^{9} /$ l, po provokacinio méginio ju skaičius reikšmingai padidèjo iki $0,51 \pm 0,21 \times 10^{9} / l(p=0,046)$. Nustatytos statistiškai reikšmingos sąsajos tarp $P S_{20 \mathrm{~A}}$ ir eozinofilu skaičiaus kraujyje prieš provokacija alergenu $(R=-0,651, p=0,030)$ ir 24 val. po jos $(R=-0,607, p=0,048)$. Išvados. Nustatyta atvirkštine sąsaja tarp $P S_{20 \mathrm{~A}}$ ir eozinofilu skaičiaus prieš ir po provokacijos D. pteronyssinus alergenu. Taigi, ryškèjant sisteminiam eozinofiliniam uždegimui, blogèja dusulio suvokimas, o tai gali būti sunkaus alerginès astmos paūmejjimo rizikos veiksnys.
\end{abstract}

Reikšminiai žodžiai: astma, dusulio suvokimas, eozinofilai, bronchu provokacija alergenu.

Summary. Introduction. In addition to the many factors that can affect perception of the dyspnea, airway inflammation also has a significant effect. The most important inflammatory cells in the pathogenesis of allergic asthma are eosinophils, which causes inflammation of the respiratory tract, manifested by increased bronchial reactivity. Unfortunately, the relationship between the dyspnea perception and eosinophils count in peripheral blood in allergic asthma has not been yet adequately investigated. Aim. To evaluate the association between the dyspnea perception and blood eosinophil count before and after the bronchial allergen challenge in patients with allergic asthma. Methodology. Eleven allergic asthma patients (mean age $31.8 \pm 9.3$ years) with normal lung function and free of inhaled steroids were examined. All patients underwent bronchial challenges with methacholine and Dermatophagoides pteronyssinus (D. pteronyssinus) allergen. Dyspnea perception was evaluated using the Borg Scale to calculate a perception score at a $20 \%$ decrease in FEV $V_{1}$ during allergen challenge test $P S_{20 A}$. Eosinophils from peripheral blood were evaluated before and $24 \mathrm{~h}$ after bronchial allergen challenge. Results. Mean dyspnea perception during allergen challenge test $\left(P S_{20 A}\right)$ was $2.97 \pm 2.31$. The mean blood eosinophil count before allergen inhalation challenge test was $0.36 \pm 0.25 \times 10^{9} / \mathrm{l}$, after provocation test it significantly increased up $0.51 \pm 10 \times 0.21^{9} / l(p=0.046)$. Statistically significant relationships were found between $P S_{20 A}$ and eosinophil count in peripheral blood before $(R=-0.651, p=0.030)$ and $24 \mathrm{~h}$ after allergen challenge $(R=-0.607, p=0.048)$. Conclusions. The inverse relationship between $P S_{20 A}$ and eosinophil count before and after allergen $D$. pteronyssinus challenge test was determined. In this way, when systemic eosinophilic inflammation is developing, the dyspnea perception is deteriorating, which can be a risk factor for a severe allergic asthma exacerbation.

Key words: asthma, dyspnea perception, eosinophils, bronchial allergen challenge. 


\section{Moksliniai darbai}

\section{IVADAS}

Dusulys - tai grèsmingas simptomas, apibūdinamas kaip pasunkèjęs kvėpavimas arba kvėpavimo diskomforto jausmas, pasireiškiantis sergant ịvairiomis, dažniausiai kvépavimo sistemos ligomis. Dusulio suvokimui reikšmès turi daugelis veiksnių, pvz., lytis, amžius, antsvoris, fizinis parengtumas, psichologinė būklè, gretutinès ligos ir pan. Atlikti tyrimai rodo, kad patofiziologiniai procesai plaučiuose, įskaitant ir kvẻpavimo takų uždegimą, gali įtakoti dusulio suvokimą [1-3].

Priepuolinis dusulys yra vienas būdingų astmos klinikinių simptomų. Astma žymiai pablogina sergančiojo gyvenimo kokybę (mažèja gebèjimas susikaupti, darbo našumas, didèja nedarbo dienų skaičius), o kartais ligos paūmèjimas gali sukelti net mirtị. Nepaisant plataus vaistų pasirinkimo, išlieka sunkios, blogai kontroliuojamos, nuolat paūmèjančios astmos atvejų. Daugèja įrodymų, kad tam įtakos turi sutrikęs dusulio suvokimas [1, 4-6]. Manoma, kad blogas dusulio suvokimas yra susijęs su padidejusia astmos paūmejjimo rizika, nes būklès blogèjimas nejuntamas arba juntamas neadekvačiai, todèl laiku nesikreipiama medicininès pagalbos [5].

Pastebèta, kad netgi panašaus sunkumo astma sergantys asmenys dusuli suvokia skirtingai [2, 7]. Dominuoja tendencija, kad sergantiesiams sunkia astma, ryškesnẻ bronchų obstrukcija kliniškai pasireiškia silpnesniu dusuliu [2, 4, 9]. Tai bandoma paaiškinti dominuojančiu eozinofiliniu kvejpavimo takų uždegimu [6]. Pastebėta, kad skreplių eozinofilija ir padidèjęs eozinofilų kiekis bronchų bioptatuose yra susijęs su dusulio suvokimu $[2,8,9]$. Ar dusulio intensyvumo suvokimas gali priklausyti nuo sisteminio eozinofilinio uždegimo, sergant astma, nèra aišku. Todèl šio tyrimo tikslas - įvertinti sergančiųjų alergine astma dusulio intensyvumo sąsajas su periferinio kraujo eozinofilu skaičiumi. Tuo tikslu tiriamiesiems buvo provokuojama ūminè bronchų obstrukcija įkvepiamuoju Dermatophagoides pteronyssinus (D. pteronyssinus) alergenu.

\section{METODIKA}

I tyrimą ịtraukti 18-50 metų asmenys, sergantys alergine astma, turintys įsijautrinimą $D$. pteronyssinus alergenui ir ne trumpiau kaip 1 mèn. nevartoję ikvepiamųų gliukokortikoidų. Visiems tiriamiesiems astmos simptomai pasireiškè ne trumpiau kaip vienerius metus, o per pastarajj ménesị iki pasirašant dalyvavimo tyrime sutikimo formą nebuvo astmos paūmèjimui būdingų simptomų.

Pirmo vizito metu visiems tiriamiesiems buvo atlikta spirograma, bronchų provokacinis mėginys su metacholinu ir alerginiai odos dūrio méginiai. Antras vizitas ìvyko vienos savaitès laikotarpiu po pirmojo, kurio metu buvo atliekamas bendrasis kraujo tyrimas, bron- chų provokacinis mėginys su $D$. pteronyssinus alergenu. Praejus 24 val. po provokacinio mėginio su alergenu, pakartotinai atliktas bendrasis kraujo tyrimas. Dusulio intensyvumas provokacinio mėginio su alergenu metu buvo vertinamas pagal Borgo skalę.

Isijautrinimas D. pteronyssinus alergenu (Stallergenes S.A., Prancūzija) vertintas atliekant odos dūrio méginius (lašinant alergeną ant vidinio dilbio odos, $3 \mathrm{~cm}$ atstumu ir per lašą praduriant epidermị su specialia adatèle). Méginio teigiamai kontrolei naudotas $10 \mathrm{mg} / \mathrm{ml}$ histamino tirpalas, neigiamai kontrolei alergenų diagnostinio tirpalo skiediklis. Odos reakcija vertinta po 15 min., liniuote išmatuojant didžiausią ir jam statmeną pūkšlès skersmenį bei apskaičiuojant aritmetini jų vidurkị (mm). Mejginys vertintas teigiamu, kai vidutinis pūkšlès dydis didesnis nei $3 \mathrm{~mm}$.

Plaučių funkcija vertinta atliekant spirogramą su „CustoVitM“ spirometru (Custo Med; Munchen, Vokietija).

Bronchų provokacinis méginys su metacholinu atliktas rezervuariniu metodu (Provocations Test I, Pari, Vokietija), pradedant nuo $15 \mu$ g metacholino ir kas 5 min. šią dozę didinant du kartus iki suminès i plaučius patenkančios $1929 \mu \mathrm{g}$ metacholino dozès. Po kiekvienos įkvèptos metacholino dozès, praejjus 30 ir 90 sek., tiriamiesiems atlikta spirograma ir vertintas forsuoto iškvėpimo tūrio per pirmąją sekundę $\left(\mathrm{FEV}_{1}\right)$ pokytis. Tyrimas nutrauktas $\mathrm{FEV}_{1}$ sumažejjus 20 proc. nuo pradinio dydžio ar atsiradus subjektyviai netoleruojamam dusuliui. Padidejęs bronchų reaktyvumas vertintas apskaičiavus provokacinę metacholino dozę $\left(\mathrm{PD}_{20 \mathrm{M}}\right)$, sumažinančią $\mathrm{FEV}_{1} 20$ proc. nuo pradinio $\mathrm{FEV}_{1}$ dydžio. Metacholino mėginys naudotas kaip astmos diagnostinis tyrimas.

Bronchų provokacinis mėginys su specifiniu D. pteronyssinus alergenu atliktas su skirtingomis specifinio alergeno (Stallergenes S.A., Prancūzija) tirpalo koncentracijomis $(0,01 \mathrm{IR} / \mathrm{ml}, 0,1 \mathrm{IR} / \mathrm{ml}, 1,0 \mathrm{IR} / \mathrm{ml}, 10 \mathrm{IR} / \mathrm{ml}$, 33,3 IR/ml), naudojant „KoKo DigiDoser“ purkštuvą (Sunrise Medical, Somerset, PA, JAV). Liofilizuotas alergenų ekstraktas skiestas 0,9 proc. natrio chlorido tirpalu. Po kiekvienos ịkvėptos alergeno dozès praejjus 10 min., atlikta spirograma ir vertintas $\mathrm{FEV}_{1}$ pokytis. Tyrimas nutrauktas $\mathrm{FEV}_{1}$ sumažejjus 20 proc. nuo pradinio dydžio arba atsiradus subjektyviai netoleruojamam dusuliui. Padidejęs bronchų reaktyvumas vertintas apskaičiavus provokacinę metacholino dozę $\left(\mathrm{PD}_{20 \mathrm{~A}}\right)$, sumažinančią $\mathrm{FEV}_{1} 20$ proc. nuo pradinio $\mathrm{FEV}_{1}$ dydžio.

Bronchų provokacinio méginio su alergenu metu dusulys vertintas balais pagal Borgo skalę kiekvieną kartą prieš atliekant spirogramas po alergeno dozių sukvèpavimo praèjus protokole numatytam laikotarpiui. Dusulio intensyvumas $\mathrm{FEV}_{1}$ sumažejjus 20 proc. nuo pradinio dydžio bronchų provokacijos alergenu 


\section{Moksliniai darbai}

1 lentelè. Tiriamujų demografiniai ir klinikiniai duomenys

\begin{tabular}{|c|c|c|c|c|c|c|c|c|}
\hline $\begin{array}{l}\text { Tiria- } \\
\text { masis }\end{array}$ & $\begin{array}{l}\text { Lytis } \\
\text { (V/M) }\end{array}$ & $\begin{array}{l}\text { Amžius } \\
\text { (metai) }\end{array}$ & $\begin{array}{l}\text { Pradinis } \\
\text { FEV }_{1} \\
\text { (litrai) }\end{array}$ & $\begin{array}{l}\text { Pradinis } \\
\text { FEV }_{1} \\
\text { (proc. } \\
\text { normos) }\end{array}$ & $\mathrm{PD}_{20 \mathrm{M}}(\mathrm{mg})$ & $\begin{array}{l}\text { Pūkšlès i } \\
\text { D. pterony- } \\
\text { sinnus alergeną } \\
\text { vidutinis skers- } \\
\text { muo (mm) }\end{array}$ & $\begin{array}{l}\text { Eozinofily̨ skai- } \\
\text { čius kraujyje } \\
\text { prieš provoka- } \\
\text { ciją alergenu, } \\
\left(\times 10^{9} / l\right)\end{array}$ & $\begin{array}{l}\text { Eozinofily̨ skai- } \\
\text { čius kraujyje } \\
\text { po provokaci- } \\
\text { jos alergenu, } \\
\left(\times 10^{9} / I\right)\end{array}$ \\
\hline 1 & $M$ & 48 & 3,37 & 127 & 0,090 & 4,0 & 0,53 & 0,61 \\
\hline 2 & V & 30 & 4,55 & 100 & 0,210 & 4,0 & 0,18 & 0,40 \\
\hline 3 & M & 41 & 2,79 & 96 & 0,073 & 5,0 & 0,35 & 0,49 \\
\hline 4 & M & 27 & 3,53 & 109 & 0,290 & 6,0 & 0,10 & 0,17 \\
\hline 5 & V & 22 & 5,17 & 98 & 0,092 & 6,5 & 0,13 & 0,50 \\
\hline 6 & V & 44 & 2,70 & 81 & 0,055 & 4,5 & 0,39 & 0,65 \\
\hline 7 & M & 24 & 3,88 & 113 & 0,353 & 6,5 & 0,65 & 0,72 \\
\hline 8 & V & 20 & 2,44 & 73 & 0,016 & 4,0 & 0,89 & 0,83 \\
\hline 9 & $M$ & 27 & 3,57 & 105 & 0,070 & 8,0 & 0,30 & 0,25 \\
\hline 10 & M & 31 & 3,50 & 102 & 0,074 & 4,0 & 0,24 & 0,65 \\
\hline 11 & $M$ & 36 & 4,49 & 139 & 0,095 & 5,0 & 0,17 & 0,33 \\
\hline \multicolumn{2}{|c|}{ Vidurkis \pm SN } & $31,8 \pm 9,3$ & $3,64 \pm 0,86$ & $104 \pm 19$ & $0,129 \pm 0,107$ & $5,5 \pm 1,3$ & $0,36 \pm 0,25$ & $0,51 \pm 0,21$ \\
\hline
\end{tabular}

$\mathrm{FEV}_{1}$ - forsuoto iškvejpimo tūris per pirmają sekundę; $\mathrm{SN}$ - standartinis nuokrypis.

metu $\left(\mathrm{PS}_{20 \mathrm{~A}}\right)$ apskaičiuotas pagal linijinès interpoliacijos metodą.

Eozinofilų skaičius kraujyje tirtas iš periferinio kraujo, paimto prieš ir 24 val. po bronchų provokacinio méginio su alergenu.

Gauti duomenys apdoroti statistine programa „SPSS 23.0“. Gauti duomenys pateikiami kaip vidurkis \pm standartinis nuokrypis. Vidurkių skirtumo statistinis reikšmingumas vertintas pagal Stjudento (t) kriterijų, koreliacija - pagal Spearmanno koreliacijos koeficientą. Rezultatai vertinti kaip statistiškai patikimi, kai $\mathrm{p} \leq 0,05$.

\section{REZULTATAI}

Ištirta 11 alergine astma sergančių asmenų, kurių demografiniai ir klinikiniai duomenys pateikiami 1 lentelèje.

Vidutinis kraujo eozinofilų skaičius prieš bronchų provokacini méginị specifiniu alergenu buvo $0,36 \pm 0,25 \times 10^{9} / 1$, po provokacinio méginio specifiniu alergenų eozinofilų skaičius kraujyje reikšmingai padidejo iki $0,51 \pm 0,21 \times 10^{9} / 1$ ( $\left.\mathrm{p}=0,046\right)$ (1 pav.).

Dusulio suvokimas bronchų provokacijos alergenu

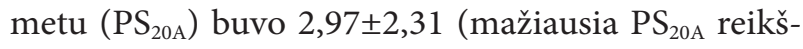
mé - 1,31, didžiausiai - 5,24).

Nustatyta vidutinio stiprumo atvirkštinė koreliacija tarp prieš ir po bronchų provokacijos alergenu kraujyje esančių eozinofilų skaičiaus ir dusulio intensyvumo $\mathrm{PS}_{20 \mathrm{~A}}$ (atitinkamai $-\mathrm{R}=-0,651, \mathrm{p}=0,030$ ir $\mathrm{R}=-0,607$, $\mathrm{p}=0,048$ ) (2 pav.).

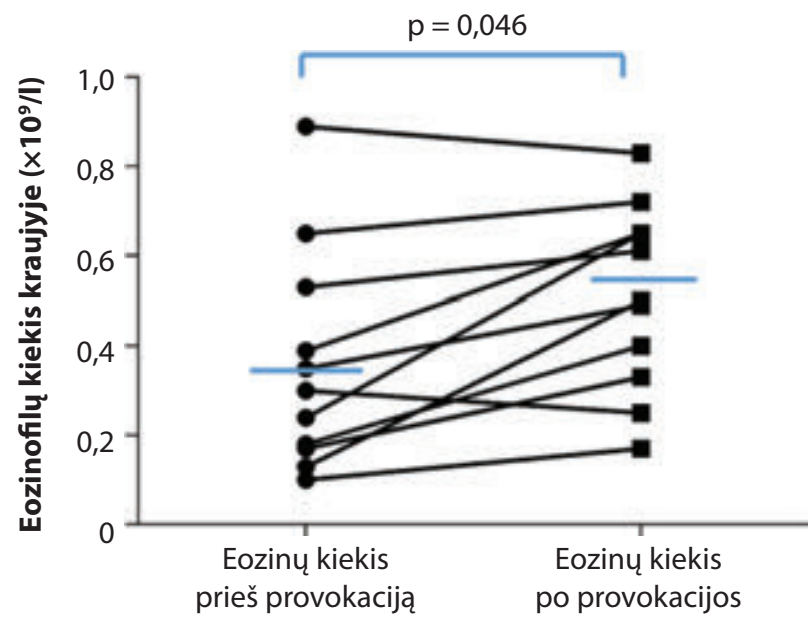

1 pav. Eozinofilų kiekis kraujyje prieš ir po bronchų provokacijos alergenu

\section{APTARIMAS}

Atlikto tyrimo duomenimis, dusulio suvokimas susijęs su periferinio kraujo eozinofilų skaičiumi sergant alergine astma. Nustatyta, kad, didejjant eozinofilų skaičiui kraujyje, silpnèja dusulio intensyvumo suvokimas. Taigi, ryškèjant sisteminiam eozinofiliniam uždegimui, blogèja dusulio suvokimas, o tai gali būti sunkaus alerginès astmos paūmèjimo rizikos veiksnys.

Dusulio suvokimą lemia keletas kvėpavimo patofiziologinių mechanizmų: plaučių hiperinfliacija, padidèjęs kvėpavimo darbas dẻl aktyvinamų kvèpa- 
Moksliniai darbai
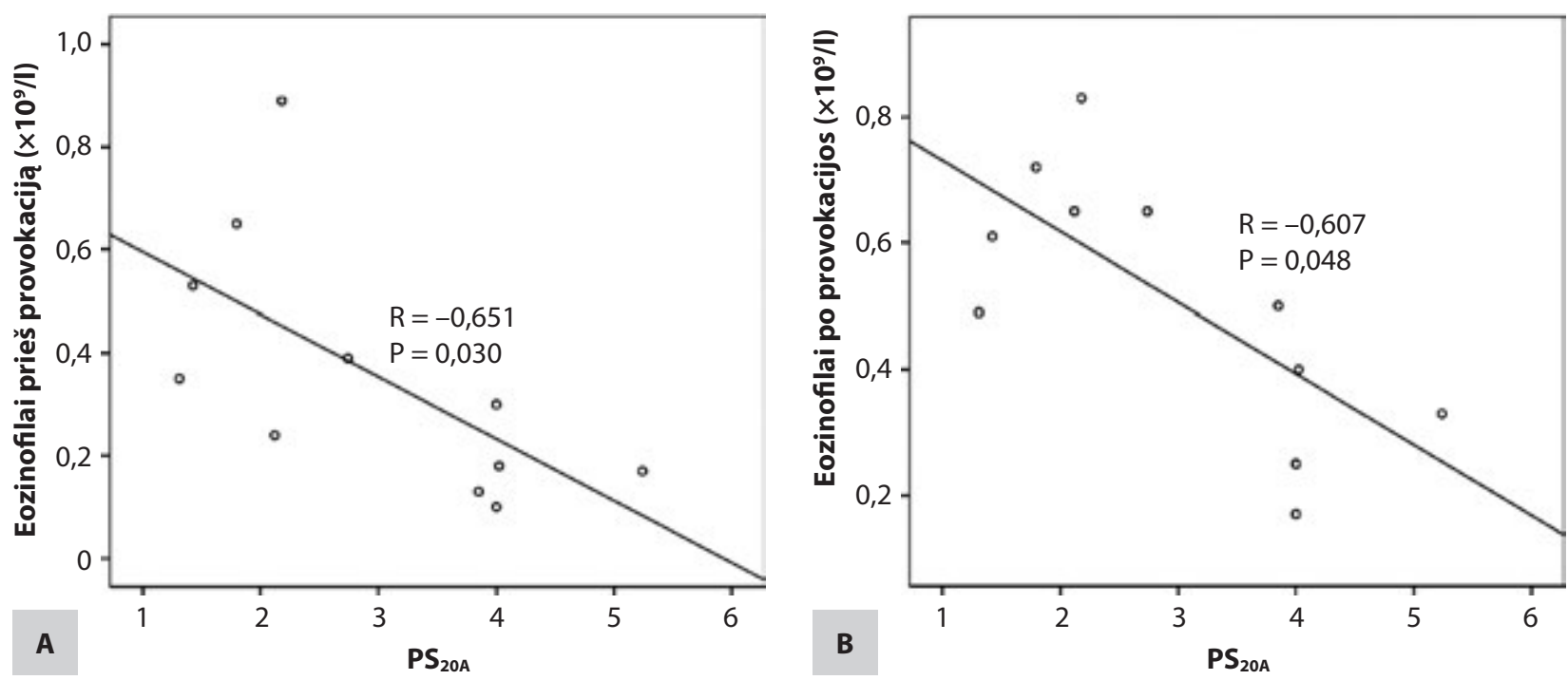

2 pav. A) koreliacija tarp PS $_{20 A}$ ir eozinofilų skaičiaus kraujyje prieš bronchų provokaciją alergenu; B) koreliacija tarp PS 20A ir eozinofilų kiekio kraujyje 24 val. po bronchų provokacijos alergenu.

$\mathrm{PS}_{20 \mathrm{~A}}$ - dusulio intensyvumas $\mathrm{FEV}_{1}$ sumažejus 20 proc. nuo pradinio dydžio bronchų provokacijos alergenu metu.

vimo raumenų proprioreceptorių, tiesioginio kvèpavimo taku mechanoreceptorių stimuliavimo [1, 10-13]. Dusulio suvokimui reikšmingos ịtakos turi ir eozinofilinis kvèpavimo taku uždegimas [1, 3, 14]. Žinoma, kad aktyvuoti eozinofilai išskiria neurotoksinus, kurie veikia aferentinius nervus, dalyvaujančius dusulio suvokime [12]. Smulkiųjų kvèpavimo takų uždegiminis procesas didina plaučių hiperinfliaciją ir ankstyvą kvėpavimo takų užsidarymą [1, 10-13]. Irodyta, kad pacientams, sergantiems sunkia astma su pasikartojančiais paūmėjimais, smulkiųjų kvėpavimo takų obstrukcija buvo ryškesnè [1]. Todèl dusulio suvokimo skirtumus būtų galima paaiškinti eozinofilinio uždegimo aktyvumo skirtumais priklausomai nuo astmos sunkumo [14]. Irodyta, kad skrepliuose ir bioptatuose randama eozinofilija, sergant sunkia astma, susijusi su dusulio suvokimu ir yra ligos blogos kontrolès rodiklis [8, 15-17].

Dusulio suvokimą gali ịtakoti daugelis veiksnių, pvz.: vyresnis amžius, ilagalaikio astmos gydymo metu mažejjantis jautrumas periferiniams dusulio signalams, moteriškoji lytis, gretutinès ligos, ypač depresija [6-9], tačiau mūsų tyrime šie veiksniai negalejo įtakoti rezultatų dẻl jauno tiriamųjų amžiaus ir santykinai trumpo ligos simptomų pasireiškimo laikotarpio, gretutinių ligu nebuvimo, o vyrų ir moterų proporcijos pasiskirstè tolygiai. Tyrime dalyvavę pacientai nebuvo gydyti ¡kvepiamaisiais gliukokortikoidais, kas galètų iškreipti eozinofilų, kaip pagrindinių astmos patogenezei būdingo lètinio uždegimo ląstelių, aktyvumą ir funkcijas.

Nèra duomenų vertinant kraujo eozinofilų skaičių ir ieškant galimų sąsajų su dusulio intensyvumo suvokimu. Nors įrodyta, kad kvėpavimo takų uždegimas atlieka svarbų vaidmenị sutrikdant (silpninant) dusulio suvokimą, esant aktyviam dominuojančiam eozinofiliniam uždegimui kvèpavimo takuose [2], tačiau eozinofilų ittaka dusulio suvokimui vertinta ne pagal periferinio kraujo, bet skrepliuose, plaučių bioptatuose randamą eozinofilų kiekį. Pirmą kartą sutrikusị dusulio suvokimą, sergant sunkios eigos astma, tyrè Veen JC su bendraautoriais [1], kurie nustatè, kad sunkia astma su dažnais paūmejjimais ir stabilios eigos astma sergantys asmenys blogiau suvokia dusulị (vertintą bronchų provokacijos metacholinu metu). Lyginant sunkia, tačiau stabilios eigos, ir sunkia, bet su dažnais paūmèjimais astma sergančiuosius, pastaroji grupe dusuli suvokè silpniau. Šio tyrimo metu nustatyta ir atvirkštinè vidutinio stiprumo koreliacija su eozinofilų kiekiu skrepliuose ir dusulio suvokimu [1, 15-17]. Todèl galima daryti išvadą, kad pacientai, sergantys sunkia astma, ypač esant vis pasikartojantiems paūmèjimams, tarsi adaptuojasi juntamam dusuliui, pradeda priimti tai kaip normą, todèl sunkiau atskiria dusulio pasunkèjimą, blogiau suvokia dusuli, kuris susijęs su skrepliuose nustatomu eozinofilų kiekiu $[1,2,16]$.

Šio tyrimo rezultatai, atliekant bronchų provokaciją specifiniu alergenu ir vertinant periferinio kraujo eozinofilų kiekį bei dusulio suvokimą, atkartojo rezultatus, gautus atliekant tyrimus, vertinusius eozinofiluc kiekio skrepliuose, plaučių bioptatuose sąsajas su dusulio suvokimu. Tai rodo, kad eozinofilai aktyvinami visame organizme, kaip sisteminis atsakas, ne vien kvèpavimo takuose, ir nèra nulemta vien lokaliai padidèjusios eozinofilų migracijos ị kvèpavimo takus. Šio tyrimo privalumas buvo ir tai, kad panaudodami ūminès alerginès astmos modelị provokuojant ịkvepiamuoju alergenu in vivo, imitavome natūralią klinikinę situaciją, kai ịprastai šiam tikslui naudojamas nespecifinis bronchų provokacinis mėginys su metacholinu. 


\section{Moksliniai darbai}

\section{IŠVADOS}

Nustatyta, kad alerginès astmos metu dusulio intesyvumo suvokimas turi atvirkštinị ryši su periferinio kraujo eozinofilų skaičiumi prieš ir po provokacijos D. pteronyssinus alergenu. Tai rodo, kad dusulio suvokimas yra silpnesnis, ryškèjant sisteminiam eozinofiliniam uždegimui. Nepakankamas dusulio suvokimas gali būti astmos paūmèjimo rizikos veiksnys, dèl to šie pacientai turètų būti atidžiai sekami ir adekvačiai gydomi.

Gauta 20170914

Priimta 20170922

\section{LITERATŪRA}

1. Veen JC, Smits HH, Ravensberg AJ, Hiemstra PS, Sterk PJ, Bel EH. Impaired Perception of Dyspnea in Patients with Severe Asthma Relation to Sputum Eosinophils. Am J Respir Crit Care Med, 1998; 158: 1134-41.

2. Barbaro MP1, Lacedonia D, Palladino GP, Bergantino L Ruggeri C, Martinelli D et al. Dyspnea perception in asthma: Role of airways inflammation, age and emotional status. Respir Med, 2011; 105:195-203.

3. Noseda A. Dyspnoea and perception of airway obstruction. Review. Rev Mal Respir, 2003; 20:364-72.

4. Stravinskaite K1, Malakauskas K, Sitkauskiene B, Sakalauskas R. Perception of Dyspnea in Asthmatics with normal lung function. Medicina, 2005; 41:747-53.

5. Malakauskas K, Ragaisiene S, Sakalauskas R. Perception of acute airway function changes by patients with mild asthma. Allergy Asthma Proc, 2009; 30:277-83.

6. Malakauskas K, Sitkauskiene B, Stravinskaite K, Sakalauskas R. Dyspnea perception and reversibility of methacholineinduced unlimited airway narrowing in asthmatics. J Asthma, 2006; 43:463-67.
7. Martinez-Moragon E, Perpina M, Belloch A, de Diego A, Martinez-Frances ME. Asthma patients' perception of dyspnea during acute bronchoconstriction. Arch Bronconeumol 2003; 39:67-73.

8. Burki NK, Lee L-Y. Mechanism of Dyspnea. Chest, 2010; 138:1196-1201.

9. Jang AS, Choi IS. Relationship between the perception of dyspnoea and airway inflammatory markers. Respir Med, 2002; 96:150-54.

10. Gigliotti F. Mechanism of Dyspnea in Healthy Subjectsa. Multidiscip Respir Med, 2010; 5:195-201.

11. Parshall MB, Schwartzstein RM, Adams L, Banzett RB, Manning HL, Bourbeau J et al. American Thoracic Society Committee on Dyspnea. An official American Thoracic Society statement: update on the mechanisms, assessment, and management of dyspnea. Am J Respir Crit Care Med 2012; 185:435-52.

12. Undem BJ, Nassenstein C. Airway nerves and dyspnea associated with inflammatory airway disease. Respir Physiol Neurobiol 2009; 167:36-44.

13. Weatherald J, Lougheed MD, Taillé C, Garcia G. Mechanisms, measurement and management of exertional dyspnoea in asthma. Eur Respir Rev, 2017; 26: 170015;

14. Lu Y, Sjöstrand $M$, Malmhäll $C$, Rådinger $M$, Jeurink $P$, Lötvall J, Bossios A. New production of eosinophils and the corresponding $\mathrm{TH} 1 / \mathrm{TH} 2$ balance in the lungs after allergen exposure in BALB/c and C57BL/6 mice. Scand J Immunol, 2010; 71:176-85.

15. Rutgers SR, ten Hacken NH, Koeter GH, Postma DS. Borg scores before and after challenge with adenosine 5'-monophosphate and methacholine in subjects with COPD and asthma. Eur Respir J, 2000; 16:486-90.

16. Rosi E, Stendardi L, Binazzi B, Scano G. Perception of Airway Obstruction and Airway Inflammation in Asthma: A Review. Lung, 2006; 184:251-58

17. van den Toorn LM, Overbeek SE. Prins JB et al. Dyspnoea perception during clinical remission of atopic asthma. Eur Respir J, 2002; 19: 1047-1050. 